\title{
Wesley e a Modernidade: A teologia de John Wesley no contexto cultural do século XVIII
}

\author{
Orientador: Paulo Fernando Carneiro de Andrade \\ Mestrando: Ewander Ferreira de Macêdo \\ Área de Concentração: Teologia Sistemático-Pastoral
}

Linha de Pesquisa: Religião e Modernidade

O estudo da teologia de John Wesley é um tema crescente no meio acadêmico, verificado especialmente a partir da década de 1960. O foco desta dissertação está na teologia de John Wesley, no contexto cultural do século XVIII; percebendo o quanto e como ele percebe e é influenciado pelo paradigma da modernidade em consolidação no Ocidente. $\mathrm{O}$ caminho escolhido para alcançar o objetivo estabelecido para esta dissertação foi verificar o processo de consolidação deste paradigma, e isto num processo gradativo, que se verificou desde os séculos X e XI com o aprimoramento e evolução da agricultura, até o contexto específico da Inglaterra dos tempos de J. Wesley. Uma vez constatado o ambiente de onde emerge a teologia wesleyana, optou-se por apresentar o desenvolvimento de sua teologia, verificando a sua relação com o fluxo provindo do contexto em que está inserido. A conclusão aponta para uma teologia encarnada e vivencial, que tem no caminho da salvação sua motivação originaria e desdobrou-se num complexo tecido teológico, fruto de um esforço de encontrar respostas para as novas perguntas que a modernidade colocou para a teologia e para o cristianismo daquele tempo.

Palavras-chave: Teologia; John Wesley; Modernidade; Inglaterra. 